\title{
CURRENT COMMUNITY-BASED MENTAL HEALTH PROMOTION STRATEGIES AMONG CHILDREN AND ADOLESCENTS: A LITERATURE REVIEW OF EVIDENCE AND FEASIBILITY IN INDONESIA
}

\author{
Ade Sutrimo $^{1}$, Lita Heni Kusumawardani ${ }^{2}$ \\ ${ }^{1}$ Department of Mental Health and Community Nursing, Faculty of Medicine, Public Health and Nursing, Universitas \\ Gadjah Mada, Yogyakarta, Indonesia \\ ${ }^{2}$ School of Nursing, Faculty of Health Sciences, Universitas Jenderal Soedirman, Purwokerto, Indonesia
}

Email : adesutrimo@ugm.ac.id

\begin{abstract}
Mental disorders impact people's quality of life globally. A quarter of the world's population consists of children and adolescents who are significantly experiencing mental disorders since the age of 14. Community-based mental health strategies are aimed to overcome the challenges of mental health. The purpose of this review was to explore the evidence of children and adolescents' mental health promotion strategies to be potentially implemented in Indonesia. A literature review design was utilized using PRISMA on 20 journals through Science Direct, Proquest, SAGE, Scopus, EBSCO, and Taylor and Francis, in the last five years, within keywords of community-based, children and adolescents, mental health promotion, strategy. Data were analyzed in a table containing the title, author, year, methodology, results, and recommendations. Several strategies can be implemented to improve mental health in children and adolescents, such as peer group approaches, parental support, and religious education. Community-based mental health promotion strategies can optimize the effective implementation. Rigorous studies on policy evaluation, readiness, pilot studies on the implementation, and other approaches are needed for the more technical implementation of community-based mental health promotion strategies.
\end{abstract}

Keywords: Community-based, children, adolescents, mental health promotion, strategy

\begin{abstract}
Abstrak. Literasi kesehatan mental berbasis komunitas bagi anak-anak dan remaja merupakan strategi global dalam bidang kesehatan untuk menghadapi masalah kesehatan mental. Tujuan dari tinjauan ini adalah untuk mengeksplorasi bukti penelitian terkait strategi promosi kesehatan mental anak-anak dan remaja yang potensial untuk diterapkan di Indonesia. Desain yang digunakan adalah tinjauan sistemik. Beberapa strategi dapat diterapkan untuk meningkatkan kesehatan mental pada anak-anak dan remaja termasuk pendekatan kelompok sebaya, dukungan orang tua, dan pendidikan agama. Strategi promosi kesehatan mental berbasis masyarakat dapat mengoptimalkan penerapan kesehatan mental yang efektif. Diperlukan studi lanjutan terkait implementasi yang lebih teknis dari strategi promosi kesehatan mental berbasis masyarakat.
\end{abstract}

Kata Kunci : Berbasis komunitas, anak-anak, remaja, promosi kesehatan mental, strategi

\section{INTRODUCTION}

Mental health disorders have significant effects on the quality of life of people. Those account for $13 \%$ of the worldwide disease burden and affect $10-20 \%$ of children and young people globally. A previous study showed the risk of depression sharply increases after puberty, within 50 to $70 \%$ rate of a recurrent episode within five years (Zimpel \& Fleck, 2014)..
In Indonesia, it was estimated that almost 50\% experienced depressive symptoms among high school students (Kemenkes RI, 2015). The prevalence of suicidal ideation is $6.8 \%$ for a year in adolescence (Naim et al., 2015). Indonesia Family Life Survey (IFLS-5) reported female adolescents were stood as the highest rank for depressive symptoms by $32.0 \%$ (Wozney et al., 2017). 
Characteristics of depression in adolescences are mostly more serious and continually affect their well-being compared to adults. Poor physical well-being and functioning are also prone to the risk of suicide (Semiun, 2010). Meanwhile, children and adolescence are crucial periods for cognitive and behavioral development. Erikson's Theory classified these periods as when individuals are looking for ideal role models to address the essential question of who they are and develop their moral and spiritual dimensions. This character building plays pivotal roles in their life phases and is linked to their constructive life outcomes (Betz et al., 2016).

The forms of interventions that school-based, religious, and others gave positive results to address mental disorders among children and adolescents because they spend more time with their peers. On the other hand, there are constrained data on integrating these techniques, which can be a compelling approach in advancing mental well-being among children and adolescents. The aim was to explore the evidence of children and adolescents' mental health promotion strategies in Indonesia.

\section{METHOD}

Journal searching was carried out through some databases, including Science Direct, Proquest, SAGE, Scopus, EBSCO, and Taylor and Francis. The keywords to search journals were mental health promotion strategies, community-based, children, and adolescents. The inclusion criteria are articles published in 2014-2019, original research, literature, or systematic review. The exclusion criteria are duplication and only available in the abstract. The following chart is how to select articles in this review:

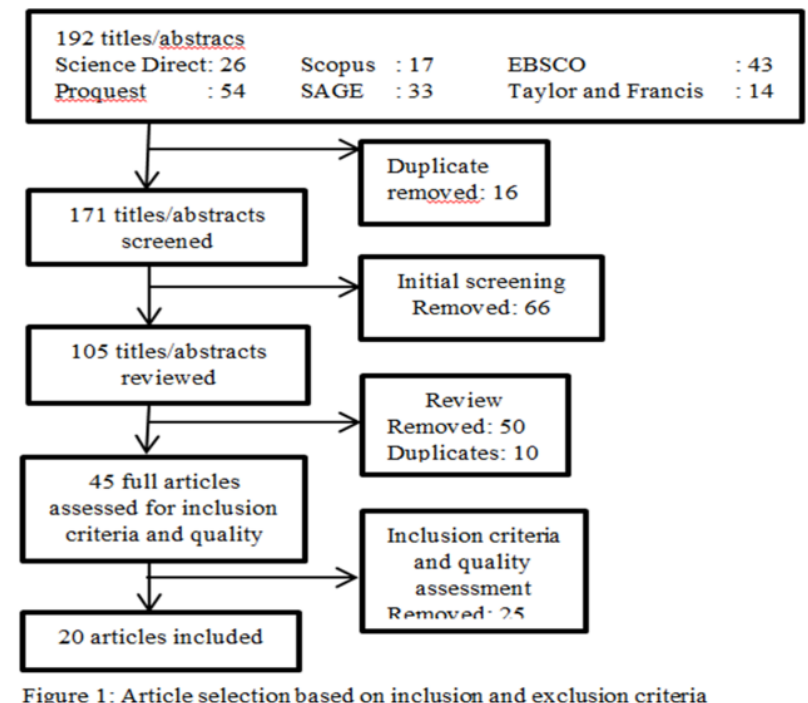

\section{RESULT AND DISCUSSION}

The obtained data were presented in table 1: author, year, participant, method, result, and then analyzed by researchers.

Table 1. The summary of articles on current community-based mental health promotion strategies among children and adolescents in 2014-2019 ( $\mathrm{n}=20)$

\begin{tabular}{|c|c|c|c|c|}
\hline $\begin{array}{l}\mathbf{N} \\
\mathbf{o}\end{array}$ & $\begin{array}{l}\text { Author \& } \\
\text { Year }\end{array}$ & Method & $\underset{\text { le }}{\text { Samp }}$ & Result \\
\hline 1. & $\begin{array}{l}\text { Tynan et } \\
\text { al (2018) }\end{array}$ & $\begin{array}{l}\text { Quasi- } \\
\text { experim } \\
\text { ent with } \\
\text { pre-and- } \\
\text { post-test }\end{array}$ & 1275 & $\begin{array}{l}\text { The connector training } \\
\text { displayed significant } \\
\text { improvements on } \\
\text { participants' confidence } \\
\text { to identify a mental } \\
\text { health problems. }\end{array}$ \\
\hline 2. & $\begin{array}{l}\text { Doi, } \\
\text { Wason, } \\
\text { Malden, } \\
\text { and } \\
\text { Jepson } \\
(2018)\end{array}$ & $\begin{array}{l}\text { A mixed } \\
\text { methods } \\
\text { study }\end{array}$ & 46 & $\begin{array}{l}\text { The program increased } \\
\text { the chances for sooner } \\
\text { identification and } \\
\text { improvement of needs } \\
\text { of health and wellbeing. }\end{array}$ \\
\hline 3. & $\begin{array}{l}\text { Petersen } \\
\text { et al } \\
(2016)\end{array}$ & $\begin{array}{l}\mathrm{A} \\
\text { narrative } \\
\text { review }\end{array}$ & 18 & $\begin{array}{l}\text { Laws and regulations to } \\
\text { control alcohol demand } \\
\text { and restrict access to } \\
\text { lethal means of suicide } \\
\text { and socio emotional } \\
\text { learning programs in } \\
\text { schools and parenting } \\
\text { programs during infancy } \\
\text { were identified as "best } \\
\text { practice". }\end{array}$ \\
\hline 4. & $\begin{array}{l}\text { Houle } \text { et } \\
\text { al (2017) }\end{array}$ & $\begin{array}{l}\text { A mixed } \\
\text { methods } \\
\text { study }\end{array}$ & 18 & $\begin{array}{l}\text { Improving residential } \\
\text { settings, and will } \\
\text { provide participatory } \\
\text { intervention strategies to } \\
\text { promote mental health. }\end{array}$ \\
\hline 5. & $\begin{array}{l}\text { Brooks et } \\
\text { al (2019) }\end{array}$ & $\begin{array}{l}\text { A mixed } \\
\text { methods } \\
\text { study }\end{array}$ & 10 & $\begin{array}{l}\text { Tools to support mental } \\
\text { health literacy and self- } \\
\text { management are a low } \\
\text { cost way in which } \\
\text { mental health services } \\
\text { can attempt to address } \\
\text { the burden of anxiety } \\
\text { and depression among } \\
\text { children and young } \\
\text { people. }\end{array}$ \\
\hline 6. & $\begin{array}{l}\text { Heslin et } \\
\text { al (2017) }\end{array}$ & $\begin{array}{l}\text { Quasi- } \\
\text { experim } \\
\text { ent with } \\
\text { pre-test- } \\
\text { post-test }\end{array}$ & 301 & $\begin{array}{l}\text { The probability of the } \\
\text { health promotion } \\
\text { intervention being cost- } \\
\text { effective for willingness } \\
\text { to pay. }\end{array}$ \\
\hline 7. & $\begin{array}{l}\text { Grandes } \\
\text { et al } \\
(2017)\end{array}$ & $\begin{array}{l}\text { Action } \\
\text { research }\end{array}$ & 21 & $\begin{array}{l}\text { The implementation } \\
\text { strategy worked at } \\
\text { bottom-up primary care } \\
\text { organizational change, } \\
\text { top-down support from } \\
\text { managers, community } \\
\text { involvement, and the } \\
\text { development of e-health } \\
\text { innovations. }\end{array}$ \\
\hline 8. & $\begin{array}{l}\text { Beidas et } \\
\text { al (2017) }\end{array}$ & $\begin{array}{l}\text { A mixed } \\
\text { methods } \\
\text { study }\end{array}$ & 15 & $\begin{array}{l}\text { Incentive-based } \\
\text { implementation } \\
\text { strategies can be } \\
\text { feasibly administered in } \\
\text { community mental } \\
\text { health agencies with } \\
\text { good acceptability. }\end{array}$ \\
\hline
\end{tabular}




\begin{tabular}{|c|c|c|c|c|}
\hline 9. & $\begin{array}{l}\text { Surjaningr } \\
\text { um, } \\
\text { Minas, } \\
\text { Jorm, and } \\
\text { Kakuma } \\
(2018)\end{array}$ & $\begin{array}{l}\text { Qualitati } \\
\text { ve } \\
\text { research } \\
\text { study }\end{array}$ & 62 & $\begin{array}{l}\text { The policy initiative is } \\
\text { feasible to the district } \\
\text { health system. A strong } \\
\text { basis within the health } \\
\text { system for task-sharing } \\
\text { mental health rests on } \\
\text { health leadership and } \\
\text { governance that open an } \\
\text { opportunity for training } \\
\text { and supervision, } \\
\text { financing, and } \\
\text { intersectoral } \\
\text { collaboration. }\end{array}$ \\
\hline 10. & $\begin{array}{l}\text { Ismail et } \\
\text { al (2016) }\end{array}$ & $\begin{array}{l}\text { Descripti } \\
\text { ve } \\
\text { (survey) }\end{array}$ & 827 & $\begin{array}{l}\text { About } 57.6 \% \text { of } \\
\text { community members } \\
\text { had good knowledge of } \\
\text { disaster, while } 26.0 \% \\
\text { had good community } \\
\text { disaster preparedness. } \\
\text { The proportions were } \\
\text { quite low. }\end{array}$ \\
\hline 11. & $\begin{array}{l}\text { Leppin et } \\
\text { al (2018) }\end{array}$ & $\begin{array}{l}\text { Intervie } \\
\text { w } \\
\text { (Qualitat } \\
\text { ive) }\end{array}$ & 35 & $\begin{array}{l}\text { Disparate nature of } \\
\text { prescribed activities that } \\
\text { different stakeholders } \\
\text { do to contribute to } \\
\text { health (physician \& } \\
\text { non-physician). }\end{array}$ \\
\hline 12. & $\begin{array}{l}\text { Hilario, } \\
\text { Oliffe, } \\
\text { Wong, } \\
\text { Browne, } \\
\text { and } \\
\text { Johnson } \\
(2015)\end{array}$ & $\begin{array}{l}\text { Scoping } \\
\text { review } \\
\text { methods }\end{array}$ & $\begin{array}{l}\text { Unrep } \\
\text { orted }\end{array}$ & $\begin{array}{l}\text { Mental health of } \\
\text { adolescent immigrants } \\
\text { (ages 10-19) diversity } \\
\text { in mental health } \\
\text { indicators, e.g., mental } \\
\text { distress, emotional } \\
\text { problems and behavioral } \\
\text { problems, as well as a } \\
\text { wide range of influences } \\
\text { on mental health from } \\
\text { age at migration and } \\
\text { length of stay to place } \\
\text { of residence, income } \\
\text { and discrimination }\end{array}$ \\
\hline 13. & $\begin{array}{l}\text { Crooks et } \\
\text { al (2018) }\end{array}$ & $\begin{array}{l}\text { Mixed } \\
\text { Method }\end{array}$ & 170 & $\begin{array}{l}\text { Strong acceptability, } \\
\text { mixed reactions to the } \\
\text { cultural adaptation, in } \\
\text { participants' knowledge, } \\
\text { mental health first aid } \\
\text { skill application, } \\
\text { awareness, and self- } \\
\text { efficacy, and reductions } \\
\text { in stigma beliefs }\end{array}$ \\
\hline 14. & $\begin{array}{l}\text { Westerlun } \\
\mathrm{d} \text { et al } \\
(2017)\end{array}$ & $\begin{array}{l}\text { A case } \\
\text { study } \\
\text { design } \\
\text { with a } \\
\text { mixed- } \\
\text { methods }\end{array}$ & 82 & $\begin{array}{l}\text { Descriptions of factors } \\
\text { influencing the initial } \\
\text { ICDP implementation. } \\
\text { Uncertainty on how to } \\
\text { manage important } \\
\text { factors and vague } \\
\text { change strategies was } \\
\text { reported. }\end{array}$ \\
\hline 15. & $\begin{array}{l}\text { Ryan, } \\
\text { Maurer, } \\
\text { Lengua, } \\
\text { Duran, } \\
\text { and } \\
\text { Ornelas } \\
(2017)\end{array}$ & $\begin{array}{l}\text { A } \\
\text { culturall } \\
\text { y } \\
\text { relevant } \\
\text { and } \\
\text { group- } \\
\text { based } \\
\text { intervent } \\
\text { ion }\end{array}$ & 24 & $\begin{array}{l}\text { Mindfulness as a way to } \\
\text { reduce stress and } \\
\text { improve mental health, } \\
\text { additional sessions of } \\
\text { the ALMA intervention } \\
\text { were developed and } \\
\text { pilot tested to provide } \\
\text { more training as a } \\
\text { coping strategy. }\end{array}$ \\
\hline
\end{tabular}

\begin{tabular}{|c|c|c|c|c|}
\hline 16. & $\begin{array}{l}\text { Van } \\
\text { Loon, } \\
\text { Van De } \\
\text { Ven, Van } \\
\text { Doesum, } \\
\text { Hosman, } \\
\text { and } \\
\text { Witteman } \\
(2015)\end{array}$ & $\begin{array}{l}\text { Cross- } \\
\text { sectional } \\
\text { and } \\
\text { longitudi } \\
\text { nal } \\
\text { approach } \\
\text { on } \\
\text { protectiv } \\
\text { e factors }\end{array}$ & 234 & $\begin{array}{l}\text { High self-esteem and } \\
\text { low use of passive } \\
\text { coping strategies were } \\
\text { related to fewer } \\
\text { internalizing and } \\
\text { externalizing problems. } \\
\text { Greater self-disclosure } \\
\text { was related to fewer } \\
\text { internalizing problems } \\
\text { and more parental } \\
\text { monitoring was related } \\
\text { to fewer externalizing } \\
\text { problems. }\end{array}$ \\
\hline 17. & $\begin{array}{l}\text { Vella et al } \\
(2018)\end{array}$ & $\begin{array}{l}\text { Intervent } \\
\text { ion of } \\
\text { the } \\
\text { Ahead of } \\
\text { the } \\
\text { Game } \\
\text { program }\end{array}$ & 542 & $\begin{array}{l}\text { Organised sports } \\
\text { represent a potentially } \\
\text { engaging avenue to } \\
\text { promote mental health } \\
\text { and prevent the onset of } \\
\text { mental health problems } \\
\text { among adolescent } \\
\text { males. }\end{array}$ \\
\hline 18. & $\begin{array}{l}\text { Estrada et } \\
\text { al (2019) }\end{array}$ & $\begin{array}{l}\text { Narrativ } \\
\text { e } \\
\text { Discussi } \\
\text { on }\end{array}$ & $\begin{array}{l}\text { Unrep } \\
\text { orted }\end{array}$ & $\begin{array}{l}\text { Religious education can } \\
\text { be instrumental to } \\
\text { improving adolescent } \\
\text { mental health by } \\
\text { developing healthier } \\
\text { reaction to stimuli; } \\
\text { reinforcing religious } \\
\text { coping mechanisms, } \\
\text { promoting a less risky } \\
\text { lifestyle; and increasing } \\
\text { religious awareness, } \\
\text { practices and influences. }\end{array}$ \\
\hline 19. & $\begin{array}{l}\text { Hamilton, } \\
\text { et } \quad \text { al } \\
(2017)\end{array}$ & $\begin{array}{l}\text { Intervent } \\
\text { ion } \\
\text { (Trial } \\
\text { Project) }\end{array}$ & $\begin{array}{c}15 \\
\text { each } \\
\text { center }\end{array}$ & $\begin{array}{l}\text { EMPOWER represents } \\
\text { a coherent program of } \\
\text { women's health } \\
\text { implementation research } \\
\text { and quality } \\
\text { improvement that } \\
\text { utilizes cross-project } \\
\text { implementation } \\
\text { strategies and evaluation } \\
\text { methodology. The } \\
\text { EMPOWER Quality } \\
\text { Enhancement. }\end{array}$ \\
\hline 20. & $\begin{array}{l}\text { Davies, } \\
\text { Knuiman } \\
\text { and } \\
\text { Rosenber } \\
\text { g (2016) }\end{array}$ & $\begin{array}{l}\text { Telepho } \\
\text { ne } \\
\text { survey }\end{array}$ & 702 & $\begin{array}{l}\text { The relationship } \\
\text { between arts } \\
\text { engagement and } \\
\text { WEMWBS was } \\
\text { nonlinear with evidence } \\
\text { of a minimum threshold } \\
\text { at } 100 \text { or more } \\
\text { hours/year. }\end{array}$ \\
\hline
\end{tabular}

Adolescence is a transition period of human development between childhood and adulthood. A necessary component of this formative arrangement is personality improvement, where a person creates individuals' capacity to think about unique concepts and the results of choices they make. This phase is also characterized by an increment in their sense of independence, driving more interaction with peers and other people (Watters \& O'Callaghan, 2016).

Changes that happen in youths influence their views of life. Their journey to create their character consists of looking for life's meaning and beliefs. Subsequently, youths address or dismiss a few thoughts instructed by grown-ups at an early age. Moreover, people create the capacity to internalize their convictions and values. 
Unfortunately, mental health problems start in this formative period, with half of the mental disorders showing as early as age 14 (Pringle et al., 2018).

Not only affects adolescence's well-being, but mental disorders also create a severe community burden. Intervention and strategies that emphasize improving mental health literacy are urgently needed to effectively decline the occurrence and recurrent mental health disorders among adolescents and young people. The mental health literacy framework needs to include both knowledge and beliefs regarding mental disorders. Individuals should aid themselves with recognition, management, or prevention related to mental health disorders. Mental health literacy protocol involves three comprehensive phases: strengths and needs assessment, action plan development, and its implementation and monitoring (Brooks et al., 2019).

Life experiences and social interaction during the transition period are also crucially needed for adolescents (Estrada et al., 2019). Previous studies demonstrated a high tendency on adolescents to seek help from peers and family instead of formal and professional procedures. Enhancing mental health literacy in education programs may be advantageous for prevention strategies on both primary and secondary levels. Intercessions such as gatekeeping programs and mental health education between peers are more successful in enhancing their information, self-esteem, and social interactions, lessening the risk factors of mental health problems (Danciu, 2014). The expected outcomes are to strengthen the networks in society in order to reduce risks, reinforce protective factors, and decrease psychiatric symptoms and disability and the onset of mental disorders (Petersen et al., 2016).

School-based psycho-educational interventions have helped diminish stigma, advance youths' mental wellbeing information, and expand mental well-being education in higher and lower-income countries (Brooks et al., 2019). Schools are a viable setting for gathering a vast population of children and youths for mental well-being advancement, and it is also imperative to reflect on the vital part of beliefs on mental well-being among this age group. School-based mental well-being education and advancement methodologies can maximize religious beliefs by emphasizing compelling usage of their beliefs to impact youthful mental well-being.

\section{CONCLUSION}

A collaborative model that integrating well-being advancement in essential and community care was doable in spurred centers. Mental well-being advancement techniques can turn into mental wellbeing data and mindfulness programs. Programs, such as detection of mental health problems in schools; early child enrichment/preschool education programs, childrearing programs on children age $2-14$ for parents; sexual orientation value and financial strengthening programs; preparing of guardians to recognize individuals with a mental health problem within the community; and preparing a community at a neighborhood level to help individuals with mental health problems. Peer approaches, parental back-up, and beliefs are required within the anticipation of mental disorders.

\section{RECOMMENDATIONS}

The programs targetting young people should apply effective strategies that include peer group approaching, school-based, community improvement because they tend to question their life values, and they are also in the character development phase who are prone to develop mental health problems. Improvements of the mental health literacy framework and its protocols will enhance adolescence mental well-being. Coordination, regulation, and intersectoral related parties' commitment will significantly improve the effectiveness and efficiency while implementing mental health literacy strategies among children and adolescents.

\section{REFERENCES}

Beidas, R. S., Becker-haimes, E. M., Adams, D. R., Skriner, L., Stewart, R. E., Wolk, C. B., ... Marcus, S. C. (2017). Feasibility and acceptability of two incentive-based implementation strategies for mental health therapists implementing cognitive-behavioral therapy: a pilot study to inform a randomized controlled trial, 1-14. http://doi.org/10.1186/s13012-017-0684-7

Betz, C. L., Cowell, J. M., Faulkner, M. S., Feeg, V. D., Greenberg, C. S., Krajicek, M. J., ... Vessey, J. A. (2016). Advancing the Development of the Guidelines for the Nursing of Children, Adolescents, and Families: 2014 Revision: Process, Development, and Dissemination. Journal of Pediatric Health Care, 30(3), 284288. http://doi.org/10.1016/j.pedhc.2015.11.003

Brooks, H., Irmansyah, I., Lovell, K., Savitri, I., Utomo, B., Prawira, B., ... Bee, P. (2019). Improving mental health literacy among young people aged 11 - 15 years in Java, Indonesia : co-development and feasibility testing of a culturally-appropriate , user-centred resource ( IMPeTUs ) - a study protocol, 2, 1-10.

Crooks, C. V, Lapp, A., Auger, M., Woerd, K. Van Der, Snowshoe, A., Rogers, B. J., ... Caron, C. (2018). A Feasibility Trial of Mental Health First Aid First Nations: Acceptability, Cultural 
Adaptation , and Preliminary Outcomes, 459471. http://doi.org/10.1002/ajcp.12241

Danciu, E. L. (2014). Specificity and Efficiency in Using Non-conventional Methods for Adolescent Education. Procedia - Social and Behavioral Sciences, 163, 104-109. http://doi.org/10.1016/j.sbspro.2014.12.293

Doi, L., Wason, D., Malden, S., \& Jepson, R. (2018). Supporting the health and well-being of schoolaged children through a school nurse programme : a realist evaluation, 1-11.

Estrada, C. A. M., Fe, M., Lomboy, T. C., Jr, E. R. G., Amalia, E., Leynes, C. R., ... Kobayashi, J. (2019). Religious education can contribute to adolescent mental health in school settings, 1-7.

Grandes, G., Sanchez, A., Cortada, J. M., Pombo, H., Martinez, C., Balagué, L., ... Gorostiza, E. (2017). Collaborative modeling of an implementation strategy: a case study to integrate health promotion in primary and community care, 1-13.

Health, J. M., Tynan, R. J., James, C., Considine, R., Skehan, J., Gullestrup, J., ... Kelly, B. J. (2018). Feasibility and acceptability of strategies to address mental health and mental ill - health in the Australian coal mining industry, 1-11.

Heslin, M., Patel, A., Stahl, D., Gardner-sood, P., Mushore, M., Smith, S., ... Gaughran, F. (2017). Randomised controlled trial to improve health and reduce substance use in established psychosis ( IMPaCT ): cost- effectiveness of integrated psychosocial health promotion, 1-14. http://doi.org/10.1186/s12888-017-1570-1

Houle, J., Coulombe, S., Radziszewski, S., Leloup, X., Saïas, T., Torres, J., \& Morin, P. (2017). An intervention strategy for improving residential environment and positive mental health among public housing tenants: rationale, design and methods of Flash on my neighborhood!, 1-12. http://doi.org/10.1186/s12889-017-4730-9

Ismail A. et al Assessing disaster preparedness and mental health of community members in Aceh , Indonesia: a community-based, descriptive household survey of a national program. (2016).

Kemenkes RI. (2015). Kesehatan dalam Kerangka Sustainable Development Goals (SDGs). Rakorpop Kementerian Kesehatan RI, (97), 24. Retrieved from http://www.pusat2.litbang.depkes.go.id/pusat2_v 1/wp-content/uploads/2015/12/SDGs-DitjenBGKIA.pdf

Naim, A., Setiawan, A., Cahyono, B. A., Handiyatmo, D., Susilo, D., Handayani, P. S., ... Rahayu, T. E. (2015). Profil Anak Indonesia 2015, 246. Retrieved from http://www.kemenpppa.go.id/v3/index.php/daftar -buku/profilanak?download=510:profilanak2012
Petersen, I., Lacko, S. E., Semrau, M., Barry, M. M., Chisholm, D., Gronholm, P., ... Thornicroft, G. (2016). Promotion, prevention and protection: interventions at the population - and community levels for mental, neurological and substance use disorders in low - and middle - income countries, 1-14. http://doi.org/10.1186/s13033016-0060-z

Pringle, J., Mills, K. L., Mcateer, J., Jepson, R., Hogg, E., \& Anand, N. (2018). The physiology of adolescent sexual behaviour: A systematic review, (2017), 1-14.

Ryan, D., Maurer, S., \& Duran, B. (n.d.). Amigas Latinas Motivando el Alma ( ALMA ): an Evaluation of a Mindfulness Intervention to Promote Mental Health among Latina Immigrant Mothers, (April 2018), 280-292. http://doi.org/10.1007/s11414-017-9582-7

Semiun, Y. (2010). Kesehatan Mental Jilid 2 (5th ed.). Yogyakarta: Penerbit Kanisius.

Surjaningrum, E. R., Minas, H., Jorm, A. F., \& Kakuma, R. (2018). The feasibility of a role for community health workers in integrated mental health care for perinatal depression : a qualitative study from Surabaya, Indonesia, 1-17.

Ward, J. S., Duncan, J. S., Jarden, A., \& Stewart, T. (2016). The impact of children's exposure to greenspace on physical activity, cognitive development, emotional wellbeing, and ability to appraise risk. Health and Place, 40, 44-50. http://doi.org/10.1016/j.healthplace.2016.04.015

Watters, C., \& O'Callaghan, P. (2016). Mental health and psychosocial interventions for children and adolescents in street situations in low- and middle-income countries: A systematic review. Child Abuse \& Neglect, 60, 18-26. http://doi.org/10.1016/j.chiabu.2016.09.002

Westerlund, A., Garvare, R., Eurenius, E., \& Lindkvist, M. (2016). Managing the initiation and early implementation of health promotion interventions: a study of a parental support programme in primary care, (8), 128-139. http://doi.org/10.1111/scs.12329

Wozney, L., Olthuis, J., Lingley-Pottie, P., McGrath, P. J., Chaplin, W., Elgar, F., ... Kennedy, J. (2017). Strongest Families ${ }^{\mathrm{TM}}$ Managing Our Mood (MOM): a randomized controlled trial of a distance intervention for women with postpartum depression. Archives of Women's Mental Health, 20(4), 525-537. http://doi.org/10.1007/s00737017-0732-y

Zimpel, R. R., \& Fleck, M. P. (2014). Depression as a major impact on the quality of life of HIVpositive Brazilians. Psychology, Health and Medicine, 19(1), 47-58. http://doi.org/10.1080/13548506.2013.772302 